\title{
Trendy w konsumpcji na rynku książki elektronicznej
}

\author{
Michat Latusek*, Tomasz Zalega**
}

Autorzy poruszaja problem trendów w konsumpcji na rynku ksiażek elektronicznych. Kluczowym ich celem jest poznanie polskiego rynku e-booków. Należy w tym miejscu wspomnieć, $\dot{z}$ e jest to rynek dopiero rozwijający się $w$ naszym kraju, dlatego też niezwykle istotne jest przeanalizowanie trendów w tym zakresie - zarówno od strony producentów, pośredników, jak i konsumentów. Analiza trendów konsumpcyjnych pozwoli również na stworzenie pewnych prognoz rozwoju tego rynku w Polsce.

Słowa kluczowe: konsumpcja, trendy w konsumpcji, e-książka

Nadesłany:07.11.2012 | Zaakceptowany do druku: 10.12.2012

\section{Consumption trends in the e-books market}

The primary purpose of the article that discusses trends in the consumption of e-books is to present the Polish market for these products. Considering that the market has started to develop only recently, it is very important that the consumption trends be analysed from the perspective of producers, intermediaries and consumers. Another aim of the analysis is to provide some indications as to how the Polish market may develop in the future.

Key words: consumption, consumption trends, e-book

Submitted: 07.11.2012 | Accepted: 10.12.2012

JEL: D03; D12; D23; R29

\section{Wprowadzenie}

Zachodzące w ostatnich latach zmiany w dziedzinie warunków życia społeczeństw często określa się w literaturze przedmiotu „rewolucją konsumpcyjną”. Podstawową przyczyną tego zjawiska jest szybki rozwój gospodarczy, zwłaszcza w takich krajach jak Rosja, Indie, Brazylia i Chiny. Ów rozwój, dzięki zjawisku korzyści skali, permanentnego postępu technicznego, a także postępującego procesu globalizacji i internacjonalizacji, przyczynił się $\mathrm{w}$ istotny sposób do masowej produkcji relatywnie tanich towarów konsumpcyjnych oraz wysokiego zatrudnienia i szybkiego wzrostu dochodów ludności. Upowszechnienie się stosunkowo wysokiej konsumpcji sprawiło, że przestała

* Mgr Michał Latusek - właściciel firmy jednoosobowej

Adres do korespondencji: e-mail: michał@skupjabłek.pl.

** Prof. UW dr hab. Tomasz Zalega - Katedra Gospodarki Narodowej, Wydział Zarządzania Uniwersytetu Warszawskiego.

Adres do korespondencji: Wydział Zarządzania Uniwersytetu Warszawskiego, ul. Szturmowa 1/3, 02-678 Warszawa, e-mail: tomasz.zalega@wp.pl. 
ona być przywilejem wyłącznie elit ekonomicznych, stając się zjawiskiem powszechnym. Dobra konsumpcyjne i usługi, kiedyś zarezerwowane wyłącznie dla najbogatszych, obecnie stają się coraz bardziej dostępne, jeśli nie dla wszystkich, to z pewnością dla milionów ludzi na całym świecie. Efektem tych zmian jest upowszechnienie się konsumpcji nowych dóbr i usług. Rzutuje to na hierarchię potrzeb, poziom, sposoby i środki ich zaspokajania, a także modyfikuje zachowania konsumpcyjne gospodarstw domowych. W konsekwencji tych zjawisk następuje także zmniejszenie się różnic kulturowych między klasami społecznymi oraz zmiana systemów wartości większości ludzi na całym świecie (Zalega, 2012, s. 126-127). Przeobrażenia te zwykło się określać w literaturze przedmiotu mianem trendów bądź tzw. nową konsumpcją. Obejmują one m.in. takie zjawiska jak: ekologizacja, multitasking, wirtualizacja, dematerializacja, gadzetyzacja, marketyzacja, dematerializacja, prywatyzacja i domocentryzacja konsumpcji. Przytoczone przykłady trendów odnoszą się zarówno do hierarchii potrzeb ludzkich, poziomu, sposobów i środków ich zaspokajania, jak i do kryteriów dokonywania wyborów. Polegają one także na upowszecnieniu się konsumpcji nowych dóbr, które są efektem postępu technicznego. Należy również nadmienić, że zjawiska te są konsekwencją dynamicznie dokonujących się przemian społecznogospodarczych zachodzących zarówno w makro-, jak i w mikroskali.

\section{Pojęcie i rozwój książki elektronicznej - ujęcie syntetyczne}

Książka elektroniczna jest cyfrowym zapisem treści, w postaci tekstu lub obrazów. Publikacja i odtwarzanie tych treści mogą odbywać się za pomocą specjalnego oprogramowania komputerowego i na przeznaczonych do tego celu urządzeniach, przystosowanych do otwierania tego rodzaju treści. Mogą to być e-czytniki, tablety, niektóre telefony lub laptopy. New Oxford American Dictionary (2001) definiuje e-book jako „elektroniczną wersję drukowanej książki, którą można odczytać na komputerze lub urządzeniu podręcznym zaprojektowanym specjalnie w tym celu". Definicja ta nie uwzględnia jednak faktu, że w dzisiejszych czasach spora część książek wydawana jest wyłącznie w formie elektronicznej, zwłaszcza w przypadku dzieł autorów niezależnych (self-publishing).

Idea książki elektronicznej narodziła się już dawno temu. Pierwszym wynalazkiem, który niewątpliwie zapoczątkował zmianę tradycyjnej formy książek, był mikrofilm. Pierwsze próby przeniesienia tekstu drukowanego na mikroklisze, w skali 160:1 powiodły się już w 1839 roku (http:// en.wikipedia.org/wiki/Microform). Wynalazek ten swoją największą popularnością cieszył się dopiero po 1925 roku, kiedy to amerykański przedsiębiorca wykorzystał mikrokliszę do modernizacji dokumentacji bankowej (http://bit.ly/M5MuBe). Trzy lata później prawa do wynalazku odkupił Eastman Kodak, dzięki któremu archiwizowanie treści za pomocą mikrofilmów stało się standardem. Warto także zaznaczyć, że mikroflimy są wykorzystywane w wielu instytucjach, takich jak biblioteki, do dnia dzisiejszego (http://blogs.smithsonianmag.com/paleofuture/2012/03/the-ipad-of-1935). Dynamiczny rozwój komputerów, powstanie protokołów TCP/IP, a także rozpowszechnienie Internetu doprowadziły w konsekwencji do tego, że mikrofilmy zostały wyparte na rzecz treści zdigitalizowanej. Sam pomysł książki elektronicznej pojawił się na długo przed jej powstaniem, głównie jako futurystyczna wizja w powieściach typu science fiction, jak chociażby Solaris Stanisława Lema z 1960 roku.

Za datę narodzin książki elektronicznej przyjmuje się czerwiec 1971 rok. Wtedy to Micheal Heart stworzył Projekt Gutenberg (http://www.gutenberg.org/). Była to inicjatywa polegająca na zdigitalizowaniu i darmowym udostępnianiu książek. Obecnie Projekt Gutenberg udostępnia ponad 38000 darmowych książek i ma olbrzymią liczbę naśladowców, przeważnie lokalnych organizacji, często o charakterze bardziej formalnym. Dobrym przykładem takiej organizacji jest chociażby Polska Biblioteka Internetowa (http://www.pbi.edu.pl). Co ciekawe, początki digitalizacji nie były niczym innym jak ręcznym przepisywaniem tekstu na komputerze. Pierwszą pozycją, jaką udostępnił Projekt Gutenberg, była amerykańska Deklaracja Niepodległości (Lebert, 2009, s. 6). Natomiast wraz z powstaniem w 1993 roku pierwszej przeglądarki internetowej Mosaic, projekt stał się coraz bardziej popularny. Wielu wolontariuszy zgłaszało się do przepisywania 
książek, w efekcie czego już w 1998 roku zasoby wzrosły dziesięciokrotnie - z 1000 do 10000 e-booków.

Pierwszym wydawnictwem, które udostępniło książkę w wersji elektronicznej, było National Academy Press. W 1994 roku w Internecie dostępnych było zaledwie parę pozycji wydawanych tradycyjnie, w całości i zupełnie za darmo. Nie trzeba było długo czekać na ruch ze strony konkurencji. Zaobserwowano bowiem ciekawy trend polegający na tym, że pozycje książkowe udostępnione w Internecie, niezależnie od tego, czy w całości, czy tylko częściowo, napędzały sprzedaż książek w tzw. twardej okładce. Akademickie wydawnictwo MIT Press zaobserwowało dwukrotnie większą sprzedaż wszystkich pozycji, które zamieścili na swojej stronie internetowej (Lebert, 2009, s. 9). Należy jednak pamiętać o tym, że w latach 90. XX wieku dostęp do Internetu był drogi, zaś samo czytanie książek na komputerze było niewygodne, $\mathrm{z}$ uwagi na brak odpowiednich standardów i urządzeń (Project Gutenberg Newsletter of October 1997). Oferowanie darmowych wersji elektronicznych książek miało wówczas charakter bardziej komplementarny do książek tradycyjnych, i oferowano je głównie w celu zachęty do kupienia wersji tradycyjnej ksiązki. Fakt ten bardzo mocno wplynął na rozwój e-booków. Początki e-publishingu dotyczą przede wszystkim książki o charakterze naukowym, akademickim. Elektroniczne wersje podręczników akademickich i publikacji naukowych były przede wszystkim tańszym rozwiązaniem od książek elektronicznych. Umożliwiały także stałe uaktualnienia, co było dużo lepszym rozwiązaniem niż coroczne reedycje. Za kamień milowy w historii e-booków uważa się powstanie w 1995 roku pierwszej księgarni online Amazon.com (http:// en.wikipedia.org/wiki/Amazon.com). Jeff Bezos, założyciel Amazonu, wybrał książki jako względnie tani produkt o olbrzymiej różnorodności (ponad 3 miliony tytułów już na samym starcie spółki). Powodów było wiele, przede wszystkim fakt, że dla większości ludzi byłby to pierwszy zakup internetowy. Produkt miał być więc tani i nieść ze sobą niewielkie ryzyko. Amazon szybko odniósł niesamowity sukces, rozszerzając swoją działalność praktycznie na cały świat. Już w 1997 roku zaczęto sprzedawać wiele nowych produktów, w tym książki w wersji elektronicznej, ciągle jednak skupiając sie na tradycyjnych wersjach. Zmienił to rok 2003, kiedy to większość nowo publikowanych książek zaczęto oferować w obu wersjach. Koszt publikacji elektronicznej był praktycznie zerowy, ograniczał się do samego przygotowania pliku. Powstały też nowe formaty i standardy, które umożliwiały wygodniejsze czytanie takich książek. Nagłe zainteresowanie sklepów internetowych sprzedażą e-booków można łączyć ze startem iTunes Store w kwietniu 2003 roku. Zaledwie pięć dni po otwarciu firma Apple sprzedała milion utworów, zaś pojedyncze utwory mp3 sprzedawane drogą elektroniczną po cenie nie wyższej niż 1 dolar amerykański. W 2010 roku Amazon ogłosił, że sprzedaż ebooków przekroczyła sprzedaż książek w twardej okładce.

Rozwój książki elektronicznej nie byłby możliwy, gdyby nie powstały odpowiednie nośniki umożliwiające wygodne i komfortowe czytanie e-booków. Początki e-książek to prosty tekst zapisany w standardzie ASCII (American Standard Code for Information Interchange). Oznaczało to jednak ograniczenie do najbardziej podstawowych fontów oraz znaków. Ostylowanie tekstu sprowadzało się tylko do podziału książki na akapity i rozdziały. Wraz z rozwojem Internetu i powstaniem pierwszej przeglądarki internetowej nastąpiła prawdziwa rewolucja w tym zakresie.

Język HTML umożliwił stworzenie tekstu zbliżonego do tekstu książki drukowanej, w efekcie czego ilustracje, tabele, kolory i style stały się dostępne. Przełomowy był 1993 rok, kiedy to firma Adobe stworzyła standard PDF (Portable Document Format), który umożliwił udostępnianie treści $\mathrm{w}$ niezmienionej formie dla każdego, niezależnie od kraju pochodzenia, systemu operacyjnego czy dostępnego oprogramowania. Adobe Reader, czyli oprogramowanie służące do otwierania plików formatu PDF, było dostępne za darmo i szybko stało się obowiązującym standardem elektronicznych dokumentów. Ponadto PDF ułatwiał prezentację, przenoszenie, dzielenie się oraz drukowanie treści tekstowo-graficznych. Oprogramowanie Adobe Acrobat, które powstało równoległe do Adobe Reader, było płatne i umożliwiało tworzenie oraz edycję takich dokumentów.

W 2000 roku Adobe kupiła firmę Glassbook, która specjalizowała się w tworzeniu elektronicznych wersji książek, zwłaszcza 
elektronicznych wersji książek dla wydawców, dystrybutorów i bibliotek (Lebert, 2009, s. 66). Posunięcie to było pierwszym krokiem firmy Adobe na rynku e-booków. Niedługo po przejęciu Glassbooka firma Adobe zaczęła oficjalną współpracę z Amazon.com i Barnes\&Noble.com, czyli dwoma największymi księgarniami sprzedającymi książki przez Internet. Współpraca $\mathrm{z}$ tymi dwoma gigantami wpłynęła na powstanie Adobe Content Server. Od tego momentu wydawca mógł decydować, jakie prawa miał nabywca danego dokumentu PDF. DRM (Digital Rights Managment) zgłaszało obawy wydawców przed naruszaniem praw autorskich książek i nielegalnym udostępnianiem plików. Ponadto DRM pozwalał dokładnie określić liczbę urządzeń, na których mogła być otwarta dana książka, a także możliwość jej drukowania czy pożyczania znajomym (funkcja dostępna np. w Amazon.com, gdzie nabywca książki ma prawo pożyczyć dany tytuł jednorazowo, na 14 dni) (http://en. wikipedia.org/wiki/Digital_rights_manage ment).

W 2001 roku Amazon i Adobe otworzyli wspólny projekt, który oferował 2000 tytułów dostępnych w Acrobat eBook Reader. W tym samym roku powstała pierwsza mobilna wersja aplikacja, która była dostępna na urządzenia PalmPilot i PocketPC. W latach 1993-2003 program Acrobat Reader został pobrany ponad $500 \mathrm{mln}$ razy. Szacuje się, że około $10 \%$ dokumentów, które są dostępne w Internecie, są właśnie dostępne w formacie PDF (Lebert, 2009, s. 67). Program Acrobat eBook Reader szybko połączył się z Acrobat Leaderem, tworząc, dostępny do dnia dzisiejszego, odpowiedzialny zarówno za obsługę tradycyjnych dokumentów PDF, jak i tych objettych specjalnymi ograniczeniami DRM i Adobe Reader.

W drugiej połowie lat 90. XX w. większość e-booków była dostępna jako tzw. plain text, czyli bardzo prosty plik tekstowy bądź jako pliki PDF. Jednakże PDF, pomimo wielu swoich zalet związanych $\mathrm{z}$ uniwersalnością i faktem, że dany dokument będzie wyglądał wszędzie tak samo, miał również sporo wad. Główne z nich to przede wszystkim rozmiar plików, który w porównaniu do zwykłego tekstu był parokrotnie, a czasem nawet kilkanaście razy większy. W czasach, gdy dostęp do szybkiego stałego łącza był ciągle luksusem zarezerwowanym na bogatszych konsumentów, miało to bardzo duże znaczenie. Często też bardziej skomplikowane książki, z wieloma wykresami i obrazkami, zajmowały dużą część zasobów komputera, co z kolei wpływało zarówno na komfort, jak i wydajność pracy z takim plikiem. Dodatkowo PDF był formatem bardzo sztywnym, ponieważ nie było możliwości zmiany wielkości czcionki w dokumencie, a także trzeba było powiększać całą stronę, co często zmniejszało wygodę czytania. Naturalną reakcją otoczenia były prace nad alternatywami dla tego formatu. W latach 90 . XX w. każda z firm pracująca nad e-bookami rozwijała własne standardy. Wspomniany Glassbook, eBookMan, Rocket eBook czy Gemstar eBook używał różnych rozwiązań, które były bardziej lub mniej do siebie zbliżone (Lebert, 2009, s. 24). Przemysł e-wydawniczy doszedł wówczas do wniosku, że potrzebna jest standaryzacja i uzgodnienie wspólnego sposobu tworzenia elektronicznych książek. W 1999 roku wypuszczona została pierwsza wersja formatu Open eBook (OeB), który był formatem opartym na strukturze XML (Extensible Markup Language) (http://www.w3.org/TR/REC$\mathrm{xml} /$ ).

$\mathrm{Z}$ kolei format ePub (electronic publication), podobnie jak jego poprzednik, jest formatem otwartym i udostępnianym na zasadzie darmowej licencji. Po raz pierwszy został on zaprezentowany we wrześniu 2007 roku (http://idpf.org/). Cechami charakterystycznymi obu tych formatów są uniwersalność i ,elastyczność" wyświetlanego tekstu. Tekst książki w formacie ePub lub OpenEbook nie jest $\mathrm{z}$ góry podzielony na strony, ale dynamicznie dostosowuje się do wielkości wyświetlacza. Jest to dużo wygodniejsze rozwiązanie niż format PDF, zwłaszcza dla urządzeń przenośnych, których wyświetlacze są często dużo mniejsze niż wielkość strony PDF.

Format ePub opiera się także na strukturze xml-owej, obsługując dodatkowo CSS. Podobnie jak standard od firmy Adobe format ePub obsługuje DRM, co oznacza, że możliwa jest aktywna kontrola praw autorskich. Najnowsza wersja formatu ePub-a, która została wypuszczona w październiku 2011 roku, wprowadza wiele ulepszeń, w postaci lepszej obsługi nowej wersji CSS-a, wielu nowych rozwiązań w temacie książek multimedialnych. Innymi słowy, można powiedzieć, że nowy 
ePub bez najmniejszego problemu obsługuje większość plików wideo oraz audio. Dzięki temu możliwe jest tworzenie książek $\mathrm{z}$ interaktywnymi animacjami, zmieniającym się tłem czy obrazkami. Obecnie takie możliwości oferuje jedynie ePub. Format ePub wspierany jest przez większość obecnych na rynku e-czytników, iPad, Sony, iRiver, Kobo, Nook oraz urządzenia z systemem Android. Wyjątkiem jest Kindle firmy Amazon, który stosuje swój własny standard moBi Pocket.

Mobipocket był francuska firmą założoną w 2000 roku, specjalizującą się w e-bookach na urządzenia PDA (Personal Digital Assistant). Format ten bazował na Openebooku. Tak samo jak OeB dostosowywał format stron do wyświetlanego urządzenia, jednak był o wiele bardziej uniwersalny i można go było otworzyć praktycznie na dowolnym urządzeniu, które obsługiwało Javę. Z tego też względu mobipocket szybko podbił rynek urządzeń przenośnych. W kwietniu 2005 roku Amazon kupił całą firmę, wszystkie prawa do formatu mobi, a także bazę ponad 80000 książek w wielu językach. Ponadto Amazon wykorzystał całe know-how oraz wiedzę pracowników Mobi do stworzenia własnej platformy i własnego standardu obsługiwanego przez przenośny czytnik e-książek Kindle. W 2011 roku Amazon zaczął promować swój autorski format i oficjalnie ogłosił koniec obsługi tego formatu. Co prawda urządzenia ciągle będą pozwalały na ich odtwarzanie, lecz w samym sklepie żadna $\mathrm{z}$ nowych pozycji nie będzie już dostępna w formacie mobipocket (http:// www.the-digital-reader.com/2011/11/02/ripmobipocket-2000-2011).

\section{Polski rynek e-książki}

Polski rynek e-książki znajduje się we wczesnej fazie rozwoju. Polskie wydawnictwa stosunkowo niedawno zaczęły interesować się tą formą książek. Liczba dostępnych tytułów w wersji elektronicznej stanowi w Polsce zaledwie $0,5 \%$ w rynku książek (tabela 1).

Na podstawie raportu UOKIK widać, że wartość polskiego rynku książki tradycyjnej w latach 2006-2009 permanentnie rosła, aczkolwiek każdego roku tempo wzrostu malało. Analogiczne wzrosty zaobserwowane zostały dla rynku sprzedaży książek w Internecie. Wzrost z 36 do 52 mln z1 jest znaczący i sugeruje, że rynek dynamicznie się rozwija. Najbardziej znaczące podmioty w przypadku sprzedaży internetowej to duże sklepy internetowe, takie jak Empik, Merlin, Gandalf oraz Selkar (Raport z badania rynku sprzedaży książek, 2011, s. 8). Największym dystrybutorem książek, prasy, filmów i muzyki w Polsce jest sieć sklepów Empik, której właścicielem jest NFI Empik Media\&Fashion. Posiada on 175 sklepów w Polsce i 19 na Ukrainie (http://empikgroup.com/o-firmie/historia/). Od 2007 roku istnieje portal internetowy empik.com na którym można dokonywać zakupów online, od 2010 roku także książek w wersji elektronicznej. Drugim podmiotem odgrywającym znaczącą rolę na rynku książek, zarówno tradycyjnych jak i elektronicznych, jest spółka akcyjna Merlin (Raport z badania rynku sprzedaży książek, 2011, s. 5). Jeśli chodzi o udziały w sprzedaży książek, to obie wspomniane firmy mają po około $20 \%$ rynku książek. Ich fuzja została zablokowana przez Urząd Ochrony Konkurencji i Konsumentów na początku 2011 roku, ze względu na zbyt dużą koncentrację i zagrożenie monopolem.

Tabela 1. Polski rynek książki elektronicznej w 2011 roku

\begin{tabular}{|l|c|}
\hline Wyszczególnienie & Wartość \\
\hline $\begin{array}{l}\text { Wielkość rynku (książka druko- } \\
\text { wana i elektroniczna) }\end{array}$ & $\begin{array}{c}694,7 \mathrm{mln} \\
\text { euro }\end{array}$ \\
\hline $\begin{array}{l}\text { Wielkość rynku (książka elektro- } \\
\text { niczna) }\end{array}$ & $\begin{array}{c}2,3 \mathrm{mln} \\
\text { euro }\end{array}$ \\
\hline $\begin{array}{l}\text { Ilość nowych tytułów na milion } \\
\text { mieszkańców }\end{array}$ & 571 \\
\hline $\begin{array}{l}\text { Ilość dostępnych pozycji elektro- } \\
\text { nicznych }\end{array}$ & 18000 \\
\hline Udział e-booków w rynku książki & $0,5 \%$ \\
\hline
\end{tabular}

Źródło: The Global eBook Market (2012, s. 24).

Empik zaczął sprzedaż e-booków 9 października 2010 roku (http://bit.ly/Nn5bRC), zaś Merlin ponad rok później, w listopadzie 2011 roku (http://media2.pl/internet/85938Merlin.pl-rusza-ze-sprzedaza-e-bookowi-audioobookow.html). Pierwsze e-booki, które pojawiły się w Polsce, były sprzedawane głównie $\mathrm{w}$ formacie PDF, z zabezpieczeniami DRM. Pomijając niedogodności związane odczytem PDF-ów na urządzeniach przenośnych, trzeba dodać, że sto- 
sowane zabezpieczenia utrudniały czytanie książek. DRM pozwalał autoryzować dany plik na jednym, czasami kilku urządzeniach odczytujących, niezależnie od tego, czy był to komputer, czy e-czytnik. Obecnie najbardziej popularnym zabezpieczeniem, opisanym w następnych podrozdziałach jest tzw. watermark, czyli stałe, bardzo trudne do usunięcia oznaczenia danego pliku (zarówno widoczne, jak i niewidoczne, które zawierają informacje o nabywcy danej książki). Książki PDF z zabezpieczeniami DRM przyjęte zostały bardzo chłodno przez polskich czytelników. Naturalną reakcją wydawców było usunięcie zabezpieczeń z plików. Kolejnym krokiem była konwersja e-booków do formatu ePub, dużo wygodniejszego dla rosnącej w sile rzeszy właścicieli urządzeń mobilnych.

Konwersją książek do plików ePub czy moBi zajmuje się w Polsce kilka firm. Pierwszą, która odniosła sukces i zaistniała na rynku, była firma Virtualo Sp. z o.o. Współpraca $\mathrm{z}$ największymi polskimi wydawnictwami pozwoliła jej na zdobycie zleceń od Empiku. Jednakże NFI Empik Media\&Fashion w niedługim czasie przejął spółkę Virtualo, odkupując 51\% jej akcji. Firma Virtualo jest obecnie liderem na rynku konwersji, zaś pozostałe firmy digitalizujące treść, takie jak Nexto, Legimi, eLib mają mniej istotne znaczenie na polskim rynku e-książek. Konwertują one jednak dużo mniej książek i starają się raczej specjalizować w e-bookach specjalistycznych, takich jak podręczniki akademickie i książki historyczne, czyli pozycjach, w których jest dużo tabel, wykresów, ilustracji lub wzorów matematycznych i które są dużo bardziej skomplikowane do przekonwertowania niż beletrystyka. Przykładowo, firma eLib w 2011 roku przekonwertowała około 700 książek i w swoim katalogu ma nieco ponad 1000 pozycji. (http://elib.pl). Dla porównania firma Virtualo w swoim katalogu ma 12600 książek (The Global eBook Market, 2012: 28).

Bazując na ofercie sklepu internetowego firmy Empik, możemy stwierdzić, że pod koniec 2011 roku dostepnych było 9937 e-booków (4521 tytułów w formacie ePub i 4068 w PDF), 1017 audiobooków oraz 7288 książek darmowych (dostępnych dla zarejestrowanych użytkowników) (http:// www.empik.pl). Liczby te są nieporównywalne do rynku amerykańskiego, gdzie dostępnych tytułów jest ponad 20 razy więcej. Podobnie sytuacja wygląda w przypadku wskaźnika mówiącego o liczbie nowych tytułów na milion mieszkańców.

Jeśli zaś chodzi o ceny e-booków w Polsce, to w lutym 2012 r. kształtowały się one na poziomie około $20,50 \mathrm{zl}$, a ponad $2 / 3$ wszystkich tytułów zawierało się w przedziale pomiędzy 10,00 a 31,00 zł. Porównując to do przeciętnej ceny książki drukowanej z 2011 r. - wynoszącej 38,40 zł, można stwierdzić, że średnik koszt zakupu e-książki kształtował się na poziomie ok. $53 \%$ książki drukowanej. Porównując polski rynek e-książki do amerykańskiego, e-book w Polsce jest ciagle dosyć drogi, ponieważ w USA cena książki elektronicznej stanowi zaledwie ok. $35 \%$ ceny książki w wersji drukowanej (http://portpublish. com/blog/). Dużym hamulcem dla obniżki cen e-booków w Polsce jest $23 \%$ podatek VAT, w porównaniu do $5 \%$ dla książki tradycyjnej. Przyczyną takiego stanu rzeczy jest polskie i unijne prawo. Interpretuje ono e-book kupiony przez Internet jako zakup usługi, a nie produktu (w przypadku zakupu tego samego pliku, fizycznie, na płycie CD zapłacimy 5\% VAT).

Jak zauważa prezes sklepu NetPress Digital B. Roszkowski, większość wydawców wydaje książki na licencjach i dokupienie możliwości wydania wersji elektronicznej książki jest ciągle stosunkowo drogie, na poziomie 1000-2000 dolarów za tytuł. Powoduje to sytuację, w której wydawcy rzadko rozszerzają swoje stare umowy, i do sprzedaży w postaci elektronicznej wchodzą głównie nowości wydawnicze (http://www. rp.pl/artykul/638669.html). W analizach szacuje się liczbę dostępnych w Polsce tytułów e-booków na około 18000 (The Global eBook Market 2012: 29).

Warto zauważyć próby tworzenia autorskich platform e-bookowych. Wspomniane wcześniej Virtualo, Woblink czy eLib.pl próbują stworzyć portale całościowo obejmujące wszystko, co jest związane $z$ ebookami, począwszy od konwersji, przez wydanie, promocję, sprzedaż i zaoferowanie własnego oprogramowania do obsługi takiej e-książki. Zarówno Woblink, jak i Virtualo oferują swoje aplikacje na urządzenia Apple i Android. Są one bardzo do siebie podobne i zbliżone do Apple Bookstore.

Jeśli zaś chodzi o czytniki, jakich używają polscy konsumenci, to dominującym rodzajem urządzeń są w dalszym ciągu urządzenia 
z wyświetlaczami LCD, powszechnie traktowane jako mniej wygodne rozwiązanie przy czytaniu e-booków. Według szacunku firmy EMPIK, w Polsce jest ok. 20000 Kindli, 7000 ONYX BooX, 30-40 000 iPadów i od 250 do 350000 iPhonów (The Global eBook Market 2012, s. 29). Jednakże urządzenia te są dla przeciętnego Polaka stosunkowo drogie.

Porównanie wielkości rynku książki elektronicznej oraz dostępności tytułów prezentuje tabela 2 . mieszkańców. W 2011 roku dla Polski wskaźnik ten wyniósł zaledwie 571 tytułów, co wypada średnio na tle takich krajów europejskich jak: Holandia, Hiszpania czy Niemcy, w których wydaje się prawie 2 razy więcej tytułów niż w naszym kraju. Jeśli zaś chodzi o dostęp do e-booków w Polsce, to jest nie najgorzej, natomiast jeżeli chodzi o liczbę dostępnych pozycji w wersji elektronicznej, nasz kraj wyprzedzają takie kraje jak: Wielka Brytania, Francja, Włochy i Niemcy. Przyjęło się mówić, że jeste-

Tabela 2. Rynek książki elektronicznej w wybranych krajach na świecie w 2011 roku

\begin{tabular}{|l|r|c|c|c|}
\hline \multicolumn{1}{|c|}{ Kraj } & \multicolumn{1}{c|}{$\begin{array}{c}\text { Wielkość } \\
\text { rynku }\end{array}$} & Nowe tytuły/1mln & $\begin{array}{c}\text { Dostepne tytuly } \\
\text { e-booki }\end{array}$ & $\begin{array}{c}\text { Udzial e-booków } \\
\text { w rynku }\end{array}$ \\
\hline USA & $21580 \mathrm{mln} €$ & 939 & 950000 & $8,9 \%$ \\
\hline Wielka Brytania & $3860 \mathrm{mln} €$ & 2459 & 1000000 & $6 \%$ \\
\hline Niemcy & $9691 \mathrm{mln} €$ & 1138 & 25000 & $1 \%$ \\
\hline Francja & $4600 \mathrm{mln} €$ & 616 & 75000 & $1,8 \%$ \\
\hline Hiszpania & $2890 \mathrm{mln} €$ & 1700 & 10000 & $2,4 \%$ \\
\hline Włochy & $3408 \mathrm{mln} €$ & 977 & 33000 & bd \\
\hline Szwecja & $277 \mathrm{mln} €$ & 463 & 4800 & bd \\
\hline Dania & $540 \mathrm{mln} €$ & 1275 & 7000 & $2 \%$ \\
\hline Holandia & $1168 \mathrm{mln} €$ & 1293 & 5000 & bd \\
\hline Austria & $792 \mathrm{mln} €$ & 1028 & bd & bd \\
\hline Słowenia & $90 \mathrm{mln} €$ & bd & 300 & $0,5 \%$ \\
\hline Polska & $697 \mathrm{mln} €$ & 571 & 18000 & bd \\
\hline Brazylia & $1352 \mathrm{mln} €$ & 271 & 10000 & bd \\
\hline Chiny & $8000 \mathrm{mln} €$ & 126 & 200000 & $1 \%$ \\
\hline Rosja & $1930 \mathrm{mln} €$ & 735 & 60000 & \\
\hline
\end{tabular}

Źródło: opracowanie własne na podstawie The Global eBook (2012).

W porównaniu do krajów europejskich w zakresie dostępnych tytułów ebooków, Polska nie wypada najgorzej. Pod tym względem nasz kraj wyprzedza nie tylko Szwecję, ale także Danię i Holandię. Pomimo że udział e-booków w rynku książek w Polsce stanowi zaledwie 0,5\%, to relatywnie dużo książek elektronicznych jest wydawanych w języku polskim. Liczba ta jest dość znacząco ograniczana przez wskaźnik mówiący o liczbie publikacji nowych książek w przeliczeniu na milion śmy 2-3 lata za tzw. rynkami rozwiniętymi. Należy jednak podkreślić, że polski rynek rozwija się bardzo dynamicznie i duże firmy związane z branżą wydawniczą starają się sukcesywnie przygotowywać się do nadchodzącej popularyzacji e-książki. Dobrym tego przykładem może być helion.pl czy spółka Agora i jej niedawno uruchomiony projekt publio.pl.

Nie należy jednak zapominać o tym, że rozwój polskiego rynku e-książek jest blokowany przez parę czynników, do których 
zaliczyć należy: wysoką stawkę VAT, ciągle wysoka cenę czytników i tabletów, a także latwy dostęp do pirackich wersji książek (serwisy P2P oraz najbardziej chyba popularny jeśli chodzi o e-booki - chomikuj.pl).

\section{Trendy w konsumpcji książek elektronicznych}

\section{Ekologizacja}

Ekologizacja konsumpcji wiąże się przede wszystkim z uświadamianiem ludzi i ich edukacją w zakresie zagrożeń dla otoczenia, w którym żyją i funkcjonują. Ruchy ekologiczne od samego początku swojego istnienia starały się wytworzyć etykę środowiska naturalnego, która funkcjonowałaby w społeczeństwie, na poziomie zarówno mikro, jak i makro. Efekty owej edukacji można było zaobserwować praktycznie od razu, począwszy od większej świadomości konsumentów objawiającej się np. segregacją śmieci czy zwiększonym popytem na dobra „ekologiczne”, po działania państwa w zakresie szeroko pojmowanej ochrony środowiska.

Coraz więcej konsumentów w swoich zachowaniach i decyzjach konsumenckich bierze pod uwagę kwestie ekologii. Ochrona środowiska i racjonalne wykorzystywanie zasobów Ziemi często mają duży wpływ na decyzje odnoszące się do tego, czy dane dobro nabyć, czy też z jego zakupu zrezygnować. Nie inaczej jest w przypadku książek elektronicznych. Jednakże odpowiedź na pytanie, co jest bardziej przyjazne środowisku naturalnemu - e-book czy książka tradycyjna - wcale nie jest taka oczywista. Wynika to głównie z tego, że niektórzy konsumenci traktują e-book jako produkt niematerialny i zużywający mniej zasobów, zapominając jednak o skutkach, jaki zostawia na środowisku naturalnym wyprodukowanie urządzeń służących do odczytu książek elektronicznych.

Amazon, w przeciwieństwie do Apple, który szczyci się byciem eco-friendly, nie udostępnia szczegółowych danych dotyczących wpływu produkcji swoich urządzeń na środowisko. The Cleantech Group przeprowadziła w 2010 roku badania i na ich podstawie opublikowała raport, z którego wynika, że przeciętny ślad, jaki pozostawia czytnik Kindle przez cały cykl swojego życia, to ekwiwalent $168 \mathrm{~kg} \mathrm{CO} \mathrm{CO}_{2}$ wyemitowanych do atmosfery. Według raportu
Apple, który przykłada szczególną wagę do stosowania rozwiązań ekologicznych (łatwo poddające się recyklingowi materiały - aluminium i szkło), tablet iPad przez cały swój lifcycle pozostawi równowartość $130 \mathrm{~kg} \mathrm{CO}$ (http://www.apple.com/environment/\#footprint). Wyprodukowanie jednego egzemplarza przeciętnej drukowanej tradycyjnie książki to około $4 \mathrm{~kg} \mathrm{CO} 2 \mathrm{w}$ atmosferze. Można zatem łatwo obliczyć, że po przeczytaniu 42 e-książek na Kindlu czy 32 na iPadzie, zaczynamy być bardziej ekologiczni. Pojawiają się jednak inne pytania: Co $\mathrm{z}$ energia potrzebna do korzystania $\mathrm{z}$ tych urządzeń? Jak wygląda sprawa recyklingu?

W przypadku obu urządzeń szacuje się, że na jeden cykl życia produktu zużywana energia odpowiada ok. 25-30\% emisji $\mathrm{CO}_{2}$ przy produkcji, a więc odpowiednio ok. $40 \mathrm{~kg} \mathrm{CO}$ dla Kindla i $30 \mathrm{~kg} \mathrm{CO}$ dla iPada. Są to wyniki, wydawać by się mogło, całkiem duże, lecz są one około 4 razy mniejsze od 13-wattowej energooszczędnej żarówki (w przeliczeniu na emisję $\mathrm{CO}_{2} /$ godzinę używania) (http://www.apple.com/ environment/\#product). Jeśli zaś chodzi o recykling, to tu sprawa wygląda dużo gorzej aniżeli w przypadku książek papierowych. W przypadku tabletów i e-czytników szacuje się, że zaledwie 13,6\% urządzeń jest poddawanych recyclingowi. Apple prowadzi swój program recyclingowy, oferując gift-cardy lub zniżki na nowe produkty (http://www.ecolibris.net/ipad.asp). Przy książkach drukowanych poziom recyclingu książek na świecie szacuje się na około 50-60\% (45\% dla USA, 77\% dla Holandii) (http://www.all-recycling-facts.com/ recycling-statistics.html).

Poniżej przedstawione zostały szacunki pokazujące zanieczyszczenie powstałe przy produkcji czytników oraz te, które nie zostały wyemitowane dzięki istnieniu książek w wersji elektronicznej (rysunek 1).

$\mathrm{Z}$ rysunku 1 wyraźnie wynika, że tempo wzrostu niewyemitowanych zanieczyszczeń dzięki e-bookom jest dużo większe aniżeli przyrost liczby urządzeń. Trend ten, wraz z rosnącą popularnością czytników oraz e-bookow, których będzie coraz więcej i które będą łatwiej dostępne, powinien się utrzymywać. Fakt ten już jest wykorzystywany przez producentów urządzeń oraz wydawców e-książek. Z badań przeprowadzonych przez firmę MobileRead Forum wynika, że jedynie $18 \%$ respondentów przyznało, że ich motywacja do korzystania 
Rysunek 1. Przewidywane zanieczyszczenie środowiska spowodowane produkcją e-czytników oraz przewidywana ilość $\mathrm{CO}_{2}$, która nie zostanie wytworzona dzięki czytanym na nich e-bookom

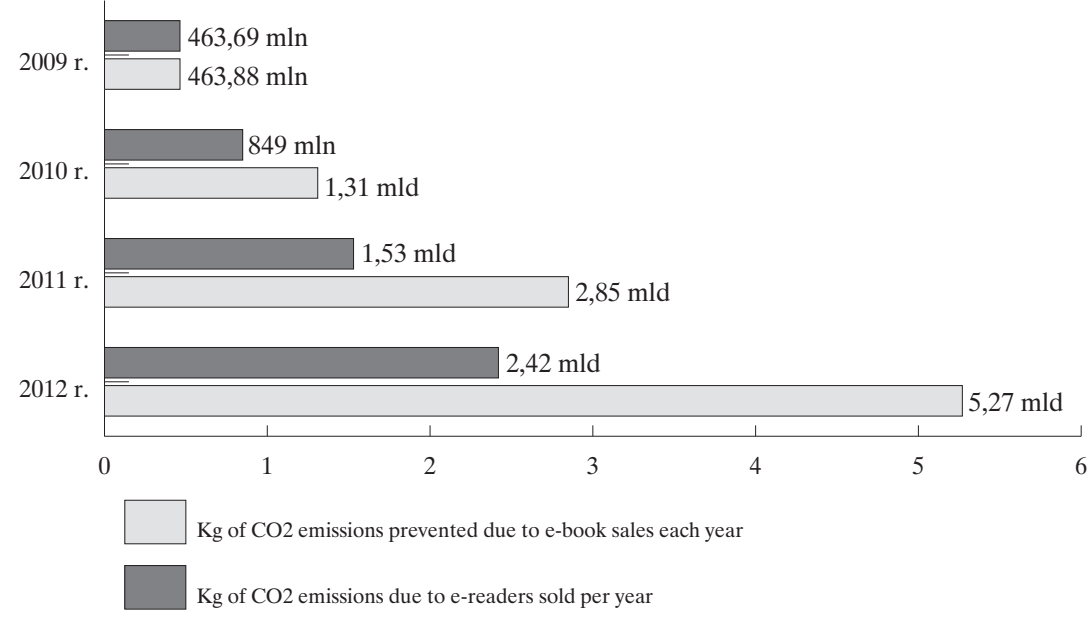

Źródło: http://www.tkearth.com/downloads/thoughts_ereaders.pdf.

z e-czytników i kupowania e-booków jest znacznie większa aniżeli przyjazność dla środowiska (http://ebooksinlibraries.blog spot.com/2012/04/ereader-and-tablet-use. html). Można zatem stwierdzić, że ekologizacja będzie korzystnym trendem zarówno dla rynku czytników, jak i samych książek elektronicznych.

\section{Multitasking}

Wirtualizacja oraz fonizacja konsumpcji spowodowały rozwój trendu nazywanego multitaskingiem, który jest umiejętnością wykonywania wielu czynności i zadań jednocześnie (Zalega, 2012, s. 131). Trend ten można zaobserwować praktycznie w życiu codziennym konsumentów, przy słuchaniu muzyki i równoczesnym czytaniu gazety czy przeglądaniu stron internetowych i równoczesnym korzystaniu z komunikatorów. Większość nowych urządzeń przenośnych, np. tabletów, daje możliwość jednoczesnego korzystania przez użytkowników z wielu aplikacji. Prawie każde nowe urządzenie typu telefon komórkowy czy e-czytnik, oprócz swoich podstawowych funkcji, umożliwia równoczesne odtwarzanie plików tekstowych, graficznych i dźwiękowych.

Zjawisko multitaskingu dla większości ludzi jest na tyle powszechne, że przestają praktycznie zwracać na nie uwagę. Nie inaczej wygląda sprawa przy korzystaniu z książek elektronicznych. Można je zaobserwować na wielu poziomach. Przede wszystkim same urzadzenia przenośne służące do odczytu e-booków są wielofunkcyjne i tym samym pozwalają na wykonywanie wielu zadań jednocześnie. Zarówno czytniki z wyświetlaczami e-ink, jak i LCD, poza możliwością otwierania plików ePub, mobi czy PDF, pozwalają użytkownikom na równoczesne słuchanie muzyki, natychmiastowy dostęp do Internetu czy działający w tle komunikator. Aplikacji, zwłaszcza w przypadku iPada jest olbrzymia liczba, i każda z nich może działać równoległe do otwartej „e-książki”. Bardzo podobnie sytuacja wygląda przy czytaniu e-booków na komputerach osobistych. Oprócz oprogramowania służącego do obsługi e-booków, uruchomionych może być równocześnie kilkanaście aplikacji. Przykładowo: czytając książkę, można mieć dostęp do informacji dotyczących bieżących wydarzeń, notowań giełdowych czy każdej innej, dowolnej treści. Dość ciekawą możliwością, która pojawiła się razem z książkami elektronicznymi, jest tworzenie odsyłaczy nie tylko wewnątrz danej książki, lecz także do zewnętrznych pozycji i źródeł. Czytając więc jedną książkę, bez problemu można kliknąć w odnośnik, który przeniesie nas na stronę internetową (większość mobilnych czytników, nawet z wyświetlaczami e-ink, ma przeglądarki internetowe) lub do księgarni/biblioteki, w której możemy nabyć pozycję, do której odnosi się autor. Drugą nowością oferowaną przez e-booki i łączącą 
się z multitaskingiem, są tzw. książki multimedialne. Od bajek dla dzieci, z wbudowanymi animacjami, piosenkami i minigrami (np. The Beatles Yellow Submarine czy Winnie the Pooh, dostępne w Apple iBookStore za darmo), po przewodniki turystyczne z multimedialnymi mapami lub dostępem do internetowych recenzji danej restauracji, pubu, wernisażu bądź muzeum. Można zatem powiedzieć, że e-booki i urządzenia służące do ich odtwarzania wpisują się w utrzymujący się obecnie trend multitaskingu, który jest naturalną reakcją na takie zjawiska, również w odniesieniu do książek elektronicznych.

\section{Wirtualizacja i dematerializacja}

Wirtualizacja oznacza coraz większy udział elektronicznych środków przekazu, takich jak: telewizja, radio czy Internet w zaspokajaniu potrzeb ludzkich. Wspomniane media zrewolucjonizowały zachowania konsumpcyjne większości ludzi, głównie w odniesieniu dóbr zaspokajających potrzeby wyższego rzędu, a zatem potrzeby w zakresie edukacji, kultury i szeroko pojmowanej rozrywki. Jak twierdzi Cz. Bywalec (2010, s. 223), wirtualizacja przejawia się w olbrzymiej swobodzie użytkowników przy wyborze treści konsumowanych. W dzisiejszych czasach kultura znaku zastępowana jest kulturą obrazu i dźwięku, tj. wizualizacją i fonizacją kultury. Proces wirtualizacji konsumpcji jest niezwykle dynamiczny i napędzany przez intensywny rozwój nowych, innowacyjnych technologii informatycznych. Wraz z popularyzacją Internetu pojawił się nowy rodzaj komunikowania się ludzi ze światem, nazy- wany w literaturze przedmiotu samokomunikacją. Blogi, mikroblogi czy portale społecznościowe stały się naturalną częścią codziennego życia olbrzymiej liczby ludzi na całym świecie, zaś same w sobie stały się przedmiotem nie tylko konsumpcji, lecz także prokonsumpcji. Wirtualizacja konsumpcji przejawia się w sposobie konsumowania najbardziej popularnych dóbr kulturowych i rozrywkowych, a ponadto koncentruje się na potrzebach jednostek. Cechą charakterystyczną wirtualizacji konsumpcji jest również możliwość przenoszenia potrzeb sfery publicznej do prywatnej (Zalega, 2012, s. 131). Obejrzenie nowego filmu, przedstawienia teatralnego, koncertu czy zrobienie prostych zakupów może się odbyć bez wychodzenia z domu. Wszystkie te potrzeby konsumenci mogą zaspokoić, korzystając z odpowiednich zasobów Internetu.

Wirtualizację, czyli dematerializację dóbr możemy zaobserwować praktycznie od II połowy lat 90 . XX wieku, gdy Internet zaczynał stawać się coraz bardziej popularny, począwszy od oprogramowania dostępnego tylko online, przez muzykę, film, prasę i książki. Porównując wszystkie te rynki i mówiąc oczywiście o produkcie cyfrowym, czyli treści zdigitalizowanej, a nie kanałach dystrybucji, można zauważyć, że książki są rynkiem bardzo małym. Sprzedaż książek to zaledwie $4 \%$ przychodów ze sprzedaży kontentu zdigitalizowanego. Dominuje oczywiście sprzedaż gier $(42 \%)$ i muzyki (32\%). Nawet sprzedaż prasy $(5 \%)$ dostarcza branży oferującej na rynek produkty cyfrowe więcej przychodów aniżeli sprzedaż e-booków (rysunek 3).

Rysunek 3. Porównanie wielkości dochodów branż sprzedających produkt cyfrowy

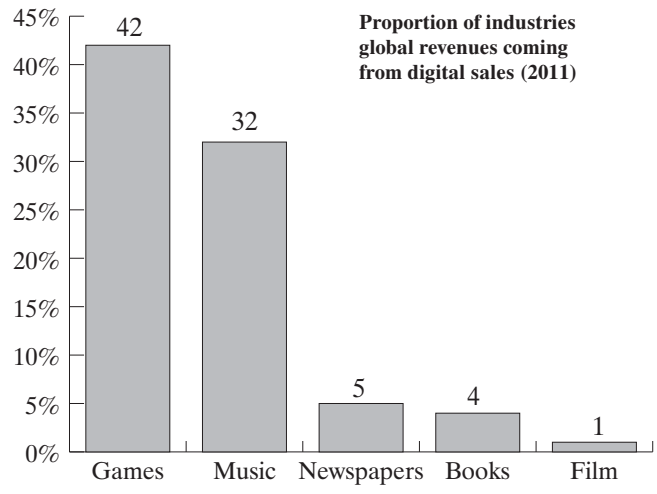

Źródło: PWC Global Entertainment and Media Outlook and IFPI. 
Jest wiele determinant, które sprawiają, że książka elektroniczna wypada tak słabo w porównaniu do muzyki czy gier. Do najważniejszych z nich, w odniesieniu do muzyki, należy zaliczyć: popularyzację urządzeń, jeden standard, niską cenę, olbrzymi wybór oraz łatwy dostęp.

Odtwarzacze mp3 stały się popularne i dostępne dla prawie każdego już na początku XXI w., zaś pojawienie się w 2003 roku iTunes Store spowodowało rewolucje na rynku muzycznym. Możliwość kupienia pojedynczych utworów po stosunkowo niskich cenach zmieniła sposób, w jaki ludzie konsumują i nabywają muzykę. Z kolei rynek gier jest bardzo charakterystyczny, z uwagi na specyficzną grupę odbiorców, którzy są mocno związani $\mathrm{z}$ nowymi technologiami. Sprzedaż gier $\mathrm{w}$ postaci niematerialnej, kanałami cyfrowymi, od samego początku była preferowana przez większość konsumentów. Natomiast w przypadku książek sytuacja wygląda nieco inaczej. Wybór pozycji książkowych w wersji elektronicznej był niewielki, nie jak w przypadku muzyki, gdzie zdecydowana większość dostępnej na rynku muzyki w formie tradycyjnej miała gotową wersję cyfrową. Czytanie ebooków jeszcze parę lat temu, gdy urządzenia typu Kindle czy iPad nie były popularne lub w ogóle jeszcze nie istniały, nie było wygodne. Ponadto, przeciętne ceny książek były niższe niż wersja drukowana, lecz ciaggle różnica nie rekompensowała braku materialnego produktu. Wszystkie te cechy w ciagu ostatnich 2-3 lat uległy znacznej poprawie, co z kolei znalazło swoje przełożenie we wzroście ich sprzedaży. Szacuje się, że liczba samych czytników będzie się co roku potrajała (http://venturebeat. com/2011/08/17/ebook-reader-sales-are-tripling-every-year/). Rozpowszechnianie się tych urządzeń, połączone z coraz niższą ich ceną, niewątpliwie wpłynie pozytywnie na cały rynek. Liczba czytników jest oczywiście bezpośrednio skorelowana $z$ liczbą sprzedanych e-booków, co oznacza, że im więcej czytników, tym lepsze wyniki e-księgarni. Trend wirtualizacji jest dla rynku e-booków jednym z najważniejszych zjawisk. Wynika to głównie $\mathrm{z}$ tego, że cała branża musi dążyć do tego, aby ułatwić konsumentom dostęp do czytników, a także rozszerzyć bazę tytułów dostępnych w wersji elektronicznej. Rozpowszechnienie e-booków z pewnością pomoże osiągnąć lepsze wyniki odnotowywane przez branże muzyki i gier komputerowych.

\section{Gadżetyzacja}

Dzięki globalizacji i unifikacji konsumpcji dobra konsumpcyjne stają się tańsze i ogólnodostępne. Produkty tańsze $\mathrm{z}$ reguły mają z góry określony krótszy cykl życia, co z kolei wiąże się z ich częstszą wymianą. Co ciekawe, nie zawsze powodem wymiany produktu jest jego zużycie fizyczne i całkowita nieprzydatność, lecz pojawienie się nowej generacji produktów, które są lekko zmodernizowane i bardzo mocno reklamowane (Bywalec, 2010, s. 233). Wywołuje to bezpośrednio wpływ nie tylko na zachowania konsumentów nabywających dobra częściej i z innych przesłanek (nowa moda, chęć zaznaczenia swojej zamożności, bycia 'na czasie' itd.), ale również na całą gospodarkę. Zjawisko to określane jest w literaturze przedmiotu marnotrawstwem konsumpcyjnym, polegającym na ciągłym dążeniu do wzmożonej konsumpcji oraz stałym poczuciu niedosytu (Zalega, 2012, s. 175). Zjawisko marnotrawstwa jest związane z tzw. paradoksem Easterlina, który informuje o tym, że wskaźnik szczęścia ludzi pozostaje stały niezależnie od wzrostu ich dochodu rozporządzalnego. $\mathrm{Na}$ podstawie przeprowadzonych badań, które trwały ponad 16 lat, Easterlin zaobserwował, że pragnienia jednostek rosły szybciej niż nabytki, zaś osiagnięcie pewnych celów konsumpcyjnych powodowało pojawienie się nowych. Trend ten w literaturze przedmiotu jest nazywany często prawem Kopernika-Greshama lub konsumpcją gadżetową. Sprowadza się ona do szybkiej wymiany produktów na ich nowsze generacje, które nie różnią się funkcjonalnością, lecz formą, wyglądem i niewielkimi modernizacjami.

Gadżetyzacja jest trendem konsumpcji, który dotyczy większości dzisiejszej elektroniki użytkowej. Każdy produkt, niezależnie od tego, czy przyznają to producenci, czy też nie, ma zaplanowany cykl życia. W dobie dynamicznego rozwoju nauki i techniki, firmy, które nie wezmą udziału w pogoni za „nowym i lepszym”, stawiają się w dużo gorszej sytuacji aniżeli firmy, które w sposób permanentny odświeżaja swoje produkty. Obecnie producenci najbardziej popularnych czytników, takich jak Amazon i Apple, wypuszczają na rynek nowe generacje swoich urządzeń średnio 
co roku (http://buyersguide.macrumors. com/ http://en.wikipedia.org/wiki/Amazon_Kindle). Nowe modele charakteryzują się zazwyczaj lepszymi podzespołami, lepszym kontrastem ekranu, nowym designem itd. Zmiany te nie mają charakteru rewolucyjnego, jednak producenci stosują wiele technik marketingowych, mających zachęcić klientów do zakupu bądź wymiany urządzenia na nowszy model. Ograniczanie możliwości wgrywania nowszej wersji oprogramowania - przykład iPada - szybko jednak zniknęło, kiedy wiele serwisów internetowych zorientowało się, że ograniczenia te wynikają z kwestii nie sprzętowych, lecz biznesowych. Analizując przykład iPada, można zaobserwować, że różnice między produktami były jedynie kosmetyczne. „Upgrade'owi” zawsze towarzyszył wzrost wydajności urządzenia o około $20 \%$ - prędkość procesora, jakość wyświetlacza oraz baterii. W każdej nowej generacji dołączana jest jedna bądź dwie funkcjonalności, których nie miał poprzedni model. Druga generacja iPada to cyfrowy aparat i multitasking (później odblokowany również w iPadzie pierwszej generacji, po odkryciu przez użytkowników, że ograniczenie zostało sztucznie nałożone przez Apple).

Zachowania konsumentów na rynku czytników wskazują na to, że duża część posiadaczy iPada czy Kindla wymienia swoje urządzenie na nowszy model, przekazując z kolei starsze modele do obiegu wtórnego, sprzedając je lub oddając rodzinie bądź znajomym. Przy premierze trzeciej generacji iPada aż $42 \%$ posiadaczy starszego modelu zadeklarowało, że kupi nowy egzemplarz, jak tylko będzie on dostępny na rynku (http://business.financialpost. com/2012/03/05/ipad-owners-looking-toupgrade/).

Trend ten jest oczywiście wykorzystywany przez producentów urządzeń, które są regularnie odświeżane, a premiery nowych generacji urządzeń są odpowiednio reklamowane. Sprzyjają temu tzw. niekontrolowane przecieki, plotki, uroczyste prezentacje oraz eventy związane $\mathrm{z}$ premierą urządzeń, które gwarantują dużą obecność produktu $\mathrm{w}$ mediach, jeszcze przed oficjalną jego sprzedażą. Niekwestionowanym mistrzem w tej dziedzinie jest Apple, o którego nowych urządzeniach jest głośno nawet pół roku przed premierą, natomiast brak jakichkolwiek konkretnych informacji o nowym produkcie, oraz budowana wokół niego atmosfery oczekiwania, nadaje charakteru wyjątkowości. Tak zaplanowana strategia sprzedaży, w połączeniu z odpowiednimi akcjami w punktach sprzedaży, polegającymi m.in. na tym, że pierwszy klient płaci za nowe urządzenie symbolicznego $1 \$$ sprawia, że w dniu sprzedaży pojawiają się olbrzymie kolejki przed sklepami.

\section{Marketyzacja}

Marketyzacja konsumpcji jest trendem, który wiąże się bezpośrednio $\mathrm{z}$ opisaną wcześniej gadżetyzacją konsumpcji. Najczęściej przez marketyzaję konsumpcji rozumie się celowe działania przedsiębiorstw, które w świadomy sposób kreują nie tylko odbiór samego produktu, ale i potrzeby konsumpcyjne odbiorców tych akcji. Z kolei Cz. Bywalec (2010, s. 237) określa marketyzację konsumpcji jako proces narastania wpływu działań marketingowych na kształtowanie się potrzeb konsumpcyjnych oraz wybór przedmiotów i sposobów ich zaspokajania.

Ciekawy może być aspekt marketyzacji konsumpcji od strony samego konsumenta nabywającego konkretny produkt. W 2010 roku Amazon wprowadził do swojej oferty czytnik, który był tańszy o $30 \$$ od dokładnie takiego samego modelu sprzedawanego wcześniej. Jedyna różnica między dwoma modelami tkwiła w tym, co wyświetlało się po zablokowaniu urządzenia. Klasyczny Kindle wyświetlał tapetę, na której były zdjęcia znanych pisarzy. Z kolei w wersji tańszej oprócz samego obrazka zaczęła się pojawiać mała ramka, zajmująca ok. $15 \%$ ekranu, w której wyświetlane były reklamy samego Amazona oraz partnerów którzy wykupili prawa do reklamy. Z marketingowego punktu widzenia reklamy są bardzo często targetowane, zaś przy zakupie czytnika każdy użytkownik, podając swoje podstawowe dane (wiek, wykształcenie, miejsce zamieszkania czy zainteresowania), oszczędzając prawie $20 \%$ na zakupie urządzenia, automatycznie stawał się odbiorcą reklam, natomiast Amazon niewielkim kosztem znalazł nowy kanał reklamy.

\section{Dematerializacja}

Dematerializacja konsumpcji jest ściśle skorelowana $z$ serwicyzacją i antropomorfizacją konsumpcji i pojmowana jest jako zjawisko permanentnego, ale i stosunkowo szybkiego wzrostu konsumpcji wartości niematerialnych. Z serwicyzacją 
konsumpcji mamy do czynienia w przypadku wzrostu udziału usług w strukturze konsumpcji gospodarstw domowych. Stopień serwicyzacji konsumpcji można wyrazić w skali mikro- i makroekonomicznej. Podejście mikroekonomiczne jest oparte na analizie badań budżetów gospodarstw domowych i sprowadza się praktycznie do ustalenia udziału wydatków na usługi konsumpcyjne w wydatkach gospodarstw domowych. Z kolei podejście makroekonomiczne opiera się na analizie podziału ostatecznego PKB i prezentuje udział usług w konsumpcji indywidualnej w sektorze gospodarstw domowych. Należy również pamiętać o tym, że serwicyzacja konsumpcji wyznacza poziom i standard konsumpcji, wpływając w istotny sposób na wzorce zachowań i styl życia. Antropomorfizacja konsumpcji przejawia się $\mathrm{w}$ poszukiwaniu w dobrach konsumpcyjnych i usługach określonych, konkretnych znaczeń i wartości niematerialnych, które są konsekwencją dążeń konsumentów pochodzących z krajów wysoko rozwiniętych gospodarczo do poszukiwania odmienności, wrażeń i pozamaterialnego sensu życia (Zalega, 2012, s. 129-130).

Dematerializacja konsumpcji jest podstawowym powodem istnienia książek elektronicznych. Wydawcy, widząc, jak dynamicznie rozwijają się rynki zdigitalizowanej muzyki czy oprogramowania, dążą do permanentnego ulepszania zarówno książek, jak i oprogramowania oraz urządzeń służących do ich obsługi. Wystarczy porównać pierwszą generację Kindle z najnowszym modelem dostępnym na rynku. Dzięki nowym technologiom dostępny jest kolorowy e-ink, zaś formaty e-książek są ciągle rozwijane - dobrym tego przykładem może być nowa wersja ePuba.

Ogólnie dąży się do tego, aby książka elektroniczna była nie tylko wygodniejsza w czytaniu, ale także oferowała konsumentowi dużo więcej atrakcji niż tradycyjny druk. Trend, jakim jest dematerializacja konsumpcji, stanowi więc motor, który nie tylko przyczynia się do konsumpcji samych ebooków, ale także napędza całą branżę, począwszy od urządzeń, a skończywszy na samym oprogramowaniu.

\section{Prywatyzacja i domocentryzacja}

Domocentryzacja konsumpcji polega na przenoszeniu konsumpcji $\mathrm{z}$ instytucji publicznych do domu, który jednocześnie staje się miejscem zaspokajania potrzeb kulturalnych, edukacyjnych, rekreacyjnych, w zakresie ochrony zdrowia itp., realizowanych wcześniej poza jego obrębem (np. w świetlicach, kinach, kawiarniach, centrach handlowych). Ten trend konsumpcji jest m.in. konsekwencją lepszego wyposażenia gospodarstw domowych w sprzęt informacyjno-rozrywkowy wysokiej klasy (telewizory LCD i plazmowe, kino domowe, wieże stereofoniczne, magnetowidy DVD, blue connect), rozwój nietypowych form zatrudnienia (zwłaszcza telepracy i pracy w niepełnym wymiarze godzin), a także permanentnie postępujący proces globalizacji, upowszechnienie Internetu i telefonii bezprzewodowej (Zalega, 2007). Należy w tym miejscu podkreślić, że wraz $z$ postępem $w$ dziedzinie informatyki i telekomunikacji, a zwłaszcza upowszechnieniem się Internetu wiąże się wirtualizacja konsumpcji. Ten rodzaj nowej konsumpcji w dużej mierze koncentruje się na zaspokajaniu potrzeb konsumpcyjnych jednostek, w dużej mierze za pośrednictwem telewizji, Internetu oraz telefonii komórkowej.

Z kolei przez prywatyzację konsumpcji rozumie się najczęściej proces indywidualizacji konsumpcji lub proces zamiany konsumpcji publicznej w konsumpcję prywatną. Domocentryzacja i prywatyzacja konsumpcji łączą się ze sobą w tym sensie, że przejawiają się ucieczką konsumentów w zacisze własnego mieszkania czy domu. Skrajnym przypadkiem tego typu zachowań jest agorafobia, czyli fobie przez „otwartą" przestrzenią publiczną. Domocentryzacja konsumpcji zmienia zachowania nabywcze konsumentów, jednakże nie można do końca stwierdzić, w jaki dokładnie sposób, gdyż konsumpcja odbywa się za zamkniętymi drzwiami mieszkań. Niewątpliwie, na skalę domocentryzacji wpływają: starzenie się społeczeństw (zwłaszcza w krajach rozwiniętych gospodarczo), rozwój technologii informatycznych oraz coraz większy odsetek ludzi pracujących w domu (na skutek rozwoju atypowych form zatrudnienia, takich jak telepraca).

Wydawcy e-booków korzystają również na istnieniu zjawiska domocentryzacji i prywatyzacji konsumpcji. Głównym kanałem sprzedaży e-booków jest oczywiście Internet. Praktycznie każdy konsument mający dostęp do Internetu, ma w zasięgu ręki całe księgozbiory. Dodatkowo, jako że ma na przykład Kindla czy iPada, od zakupu 
dzieli go wyłącznie jedno kliknięcie. Kupując czytnik Kindle, konsument otrzymuje go w postaci skonfigurowanej i zalogowanej z kontem Amazon.

Zarówno iPad, jak i Kindle sprzedaja swoje urządzenia w wersjach $3 \mathrm{~g}$, co oznacza, że mając dostęp do Internetu za pomocą sieci komórkowych, konsument wszędzie tam, gdzie jest zasięg jego telefonu, będzie mógł zalogować się do sklepu i dokonać zakupu wybranej pozycji. W przypadku Kindle, dostęp do sieci $3 \mathrm{~g}$ jest darmowy na całym świecie. Oznacza to, że za pomocą wbudowanej przeglądarki, konsument może korzystać nie tylko ze sklepu Amazon, ale także ze wszystkich dostępnych zasobów Internetu. Wszystkie te udogodnienia wprowadzane sa przed producenta to po, aby ułatwić konsumentom nabywanie e-książek. Rozwiązania te są idealne głównie dla tych konsumentów, którzy mieszkają w małych miejscowościach i mają utrudniony dostęp do księgarni i bibliotek, są zapracowani i narzekaja na deficyt czasu wolnego, bądź preferują spędzanie czasu wolnego w domu. Trend ten $\mathrm{z}$ pewnością będzie się $\mathrm{w}$ dalszym ciągu umacniał i niewątpliwie będzie bardzo pozytywnie wpływał na rynek e-booków.

\section{Podsumowanie}

Olbrzymi potencjał rynku e-booków jest ściśle skorelowany $\mathrm{z}$ postępem technicznym. Ponadto zyski, jakie osiągają producenci ze sprzedaży czytników i książek elektronicznych, z roku na rok są coraz większe. Niskie, a właściwie bliskie zeru koszty krańcowe produkcji, dystrybucji czy magazynowania przyczyniają się do dynamicznego rozwoju tego rynku. Na rozpowszechnianie się książek elektronicznych, a także pojawianie się nowych tytułów dostępnych wyłącznie w wersji cyfrowej, wpływać będą stosunkowo niskie koszty wytworzenia i opublikowania nowych pozycji. Z ekonomicznego punktu widzenia koszty digitalizacji zwracają się producentowi po sprzedanych kilku książek, zaś prowizje wydawców internetowych są dużo korzystniejsze niż te zwyczajowo przyjęte w branży książek drukowanych. Główne trendy w tzw. nowej konsumpcji będą niewątpliwie wzmacniały rozwój rynku, a także będą pozytywnie wpływały na poziom konsumpcji książek elektronicznych. E-book, w stosunku do ksiązki tradycyjnej, jest nie tylko bardziej ekologiczny, lecz także łatwiej dostępny i niematerialny, zaś do jego odczytu można stosować urządzenia będące wielofunkcyjnymi nowinkami technologicznymi. Zjawiskiem, które niewątpliwie hamuje rozwój rynku książek elektronicznych, jest piractwo oraz obawa wydawców przed nową formą dystrybucji swoich produktów. Obawa ta wynika głównie z łatwiejszego nielegalnego skopiowania książki oraz z faktu, że dobre wyniki sprzedaży e-booków będą „kanibalizować" rynek książki drukowanej. Zjawisko to można już zaobserwować na rynkach brytyjskim czy amerykańskim. Dodatkowo trendy, które w najbliższej przyszłości będa negatywnie wpływały na poziom i strukturę konsumpcji e-booków, związane są głównie $\mathrm{z}$ niskim i permanentnie spadającym poziomem czytelnictwa wśród społeczeństwa polskiego. Rozwój postępu technicznego oraz dalsza popularyzacja e-booków wśród konsumentów wydają się nieuniknione. Opisanych słabych stron czy zagrożeń rynku książki elektronicznej jest zdecydowanie mniej aniżeli zalet. Należy również podkreślić, że rynek książki elektronicznej idealnie wpasowuje się w opisane współczesne trendy konsumpcji oraz zachowania konsumentów na rynku. Ponadto wydawanie książek elektronicznych jest korzystne nie tylko dla wydawców czy autorów, ale również konsumentów - czytelników. Nikt oczywiście nie mówi o całkowitym wyparciu książki tradycyjnej z rynku, gdyż jest ona zbyt głęboko osadzona w naszej kulturze oraz mentalności konsumentów (zwłaszcza tych starszych). Można jedynie powiedzieć, że książka elektroniczna jest na chwilę obecną dobrą alternatywą dla książki drukowanej, jednakże alternatywą, która $\mathrm{z}$ roku na rok będzie powoli zmniejszała znaczenie książki drukowanej.

\section{Bibliografia}

Bywalec, Cz. (2010). Konsumpcja a rozwój gospodarczy $i$ spoleczny. Warszawa: Wydawnictwo C.H. Beck.

Lebert, M. (2009). A Short History of eBooks. Toronto: NEF, University of Toronto.

New Oxford American Dictionary (2001). Oxford: Oxford University Press.

Project Gutenberg (1997). Newsletter of October, maj-czerwiec.

Raport z badania rynku sprzedaży ksiażek, muzyki $i$ multimediów w Polsce 2011. Warszawa: Urząd Ochrony Konkurencji i Konsumentów. 
The Global eBook Market: Current Conditions \& Future Projections 2012. Rüdiger Wischenbart, O’Reilly Media, Inc., styczeń.

Zalega, T. (2007). Konsumpcja - podstawy teoretyczne. Warszawa: Wydawnictwo Naukowe Wydziału Zarządzania UW.

Zalega, T. (2012). Konsumpcja. Determinanty, teorie i modele. Warszawa: PWE.

http://en.wikipedia.org/wiki/Microform

http://bit.ly/M5MuBe

http://blogs.smithsonianmag.com/paleofuture/2012 /03/the-ipad-of-1935

http://www.gutenberg.org/

http://www.pbi.edu.pl

http://en.wikipedia.org/wiki/Digital_rights_manage ment

http://www.w3.org/TR/REC-xml/

http://www.the-digital-reader.com/2011/11/02/rip -mobipocket-2000-2011 http://empikgroup.com/o-firmie/historia/

http://media2.pl/internet/85938-Merlin.pl-rusza-zesprzedaza-e-bookow-i-audioobookow.html

http://bit.ly/Nn5bRC

http://elib.pl

http://www.empik.pl

http://www.rp.pl/artykul/638669.html

http://www.apple.com/environment/\#product

http://www.all-recycling-facts.com/recycling-statis tics.html

http://ebooksinlibraries.blogspot.com/2012/04/ereader-and-tablet-use.html

http://venturebeat.com/2011/08/17/ebook-readersales-are-tripling-every-year

http://buyersguide.macrumors.com

http://en.wikipedia.org/wiki/Amazon_Kindle

http://business.financialpost.com/2012/03/05/ipadowners-looking-to-upgrade/ 